\title{
Physical, water and redox properties of vertisols of the Sępopol Plain in north-eastern Poland
}

\author{
Mirosław Orzechowski ${ }^{1 *}$, Sławomir Smólczyński ${ }^{1}$, Barbara Kalisz ${ }^{1}$ \\ ${ }^{1}$ University of Warmia and Mazury in Olsztyn, Department of Soil Science and Land Reclamation, Plac Łódzki 3, 10-722 Olsztyn, Poland \\ * Dr hab. inż. M. Orzechowski, miroslaw.orzechowski@uwm.edu.pl, ORCID iD: https://orcid.org/0000-0002-0041-8525
}

\author{
Received: 03.03.2020 \\ Accepted: 23.06.2020 \\ Associated editor: C. Kabała
}

\section{Keywords}

Vertisols

Glaciolimnic sediments

Physical properties

Water retention

Redox potential

\begin{abstract}
Vertisols occurring in the Sępopol Plain in north-eastern Poland are characterized by high natural fertility. They belong to the group of soils with high clay content, which show the ability of periodic shrinking and swelling of clay minerals. As a result of variable moisture conditions, deep cracks and sliding surfaces are formed on the surface of the soil aggregates. The purpose of this research was to determine the chemical, physical, air-water and redox properties of vertisols developed from glaciolimnic sediments of the Weichselian glaciation, and having textures of clay (C), loam (L) and heavy clay (HC). The studied soils had high field water capacity (pF 2.0) and high content of water unavailable to plants ( $\mathrm{pF} 4.2$ ), as well as low volume of air pores. A significant positive correlation was found between the amount of clay and the volume of water unavailable to plants (pF 4.2), and a negative correlation between the amount of clay and content of water available to plants (AWC), including water readily available to plants (RAWC). The distribution of soil pores was unfavourable, and the ratio of macropores to mesopores to micropores in humic horizons was 1:2.7-5.1:1.5-5.4. The studied vertisols had low values of redox potential (Eh) and oxygen diffusion rate (ODR). The values of the Eh were above $300 \mathrm{mV}$, a threshold value for oxidised and reduced soil, only in surface horizons.
\end{abstract}

\section{Introduction}

Vertisols were separated as a new taxonomic unit in the fifth (Polish Soil Classification 2011) and the sixth (Kabała et al., 2019) edition of Polish Soil Systematics (SGP6). In the SGP6 they were classified into the type of vertisols in the order of swelling soils. These soils contain $\geq 30 \%$ of clay fraction and have a wertik horizon of thickness of $\geq 25 \mathrm{~cm}$. Vertisols have fusiform or lenticular structural aggregates and/or sliding surfaces (slickensides) in $\geq 10 \%$ of the soil volume. Vertisols are soils which origin is closely related to the lithology and mineralogical composition of the parent material. As a result of swelling and shrinking of soil rich in clay minerals, deep cracks are formed (Kovda and Wilding, 2004; Łabaz and Kabała, 2014; IUSS Working Group WRB, 2015; Kabała et al., 2019, Miller et al., 2010). Due to their high natural fertility, vertisols are an important soil group widespread in countries such as Australia, China, India, (Wilding, 2004) USA (Miller et al., 2010), Senegal, Romania, Turkey, Bulgaria, Hungary, Serbia and southern Spain (Ahmad, 1996; Favre et al., 1997; DeCarlo and Caylor, 2019). On the Earth's surface, the majority of vertisols occur in the equatorial and subtropical zone. In Poland, vertisols occur in the southwestern part, near Wrocław (Łabaz and Kabała, 2014; Kabala et al., 2015; Dudek et al., 2019), near Ciechanów (Olszewski, 1956) and in the northern part of the country above $54^{\circ} \mathrm{N}$ - in the Sępopol Plain (Uggla and Witek, 1956; Długosz et al., 2009; Orzechowski et al., 2018) and around Gniew in the Starogard Lakeland (Prusinkiewicz, 2001; Mocek et al., 2009).

The origin of vertisols in Sępopol Plain is associated with the deglaciation of ice-dammed lakes of Pomeranian phase of Weichselian glaciation and accumulation of glaciolimnic deposits (Körnke, 1930; Roszko, 1968). These deposits were parent materials for black earths and vertisols of specific chemical, physical and hydraulic properties (Uggla and Witek, 1958; Orzechowski et al., 2018). The mentioned soils are compacted with low infiltration coefficient, frequently under gleyic conditions, which suggest reducing conditions in soils. In the past, due to the „heavy“ granulometric composition, these soils were used as permanent grasslands. The use of these soils for grazing with average annual precipitation in the range of 580-600 $\mathrm{mm}$ and average annual air temperature of $7.2^{\circ} \mathrm{C}$ was beneficial for the development of grass vegetation and accumulation of soil humus (Uggla and Witek, 1958; Suchecki, 2010). Currently, vertisols are cultivated and winter wheat, winter oilseed rape, sugar beet and maize are grown on these soils. 
The purpose of this research was to determine the chemical, physical, air-water and redox properties of vertisols developed from fine-grained glaciolimnic sediments in young glacial landscape of north-eastern Poland.

\section{Materials and methods}

The research was carried out in the Sępopol Plain and northern parts of the Masurian Lakeland - the areas of icedammed lakes origin of the Weichselian glaciation (Vistula) of the Pomeranian phase (Fig. 1). At five sites of ice-dammed lakes origin, with different size, relief, hypsometry and soil cover, five soil profiles were studied: near Reszel - Black vertisols (SGP6) Pellic Vertisol (Aric, Mollic, Hypereutric, Grumic, Endostagnic) - WRB 2015, $\left(054^{\circ} 02^{\prime} 53.90 \mathrm{~N} 021^{\circ} 05^{\prime} 31.93 \mathrm{E}\right.$, located at $94.5 \mathrm{~m}$ a.s.l.) and Typical vertisols - Haplic Vertisol (Aric, Grumic, Hy-

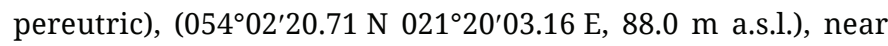
Kętrzyn - Gleyic vertisols - Haplic Vertisol (Mollic, Hypereutric, Gleyic) $\left(054^{\circ} 02^{\prime} 28.80 \mathrm{~N} 021^{\circ} 20^{\prime} 34.32 \mathrm{E}, 94.5 \mathrm{~m}\right.$ a.s.l.), near Sępopol - Typical vertisols - Haplic Vertisol (Aric, Hypereutric, Mazic), $\left(054^{\circ} 18^{\prime} 03.89 \mathrm{~N} 021^{\circ} 05^{\prime} 43.58 \mathrm{E}, 41.5 \mathrm{~m}\right.$ a.s.l.), and near Lidzbark Warmiński - Typical vertisols - Haplic Vertisol (Aric, Hypereutric, Grumic), (05409'54.19 N 020³2'31.73 E, 90.0 m a.s.l.). Black and typical vertisols were under crop cultivation while gleyic vertisols were under permanent grasslands. The studied vertisols do not occur in large soil complexes, but in various geomorphological structures forming a mosaic with other soil types (black earths, lessive soils and brown soils).

In collected soil samples, using standard methods for mineral soil studies, the following soil properties were determined: soil texture by Bouyoucos-Cassagrande method modified by Prószynski, $\mathrm{pH}$ in $\mathrm{H}_{2} \mathrm{O}$ and in $1 \mathrm{~mol} \mathrm{dm}^{-3} \mathrm{KCl}$ by the potentiomet- ric method. The content of organic carbon (TOC) and total nitrogen (TN) was analysed using a CN Vario Max Cube Elementar analyser, the content of exchangeable base cations $\left(\mathrm{Ca}^{2+}, \mathrm{Mg}^{2+}\right.$, $\mathrm{K}^{+}, \mathrm{Na}^{+}$) was determined in the extract of ammonium acetate $\left(1 \mathrm{~mol} \mathrm{dm}{ }^{-3}\right)$ at the $\mathrm{pH}$ of $7.0 . \mathrm{Ca}^{2+}, \mathrm{Mg}^{2+}, \mathrm{K}^{+}$and $\mathrm{Na}^{+}$were determined using iCAP 7400 ICP-OES Termo Scientific spectrometer. Hydrolytic acidity (HA) was determined by the method of Kappen after extraction in $1 \mathrm{~mol} \mathrm{dm}^{-3} \mathrm{CH}_{3} \mathrm{COONH}_{4}$ (Van Reeuwijk, 2002). The cation exchange capacity (CEC) was calculated as the sum of total exchange bases (TEB) and HA.

Particle density (Sd) was determined by pycnometric method and soil bulk density (Bd) in undisturbed $100 \mathrm{~cm}^{3}$ soil samples taken at four replications, steel cylinders. Total porosity (Tp) was calculated according to the equation: $\mathrm{Tp}=(\mathrm{Sd}-\mathrm{Bd}) \times \mathrm{Sd}^{-1} \times 100(\%)$.

Soil water retention properties were determined using lowpressure (in pF range 0-2.7) and high-pressure (in pF range 3.04.2) chambers. Water capacities $(\mathrm{Wv} / \mathrm{v})$ were examined at water potential of $98.1 \mathrm{hPa}(\mathrm{pF} 2.0$ ), $981.0 \mathrm{hPa}$ (pF 3.0) and 15547.9 $\mathrm{hPa}(\mathrm{pF}$ 4.2). The volume of the following soil pores and water capacities were calculated: macropores (total porosity-Wv/v at $\mathrm{pF} 2.0$ ), micropores ( $\mathrm{Wv} / \mathrm{v}$ at $\mathrm{pF} 4.2$ ), mesopores (Wv/v at $\mathrm{pF} 2.0$ $\mathrm{Wv} / \mathrm{v}$ at $\mathrm{pF}$ 4.2). Mesopores are related to potential useful water retention because they contain water available to plants (AWC - available water capacity). Among AWC, readily available water capacity - RAWC (Wv/v at pF $2.0-\mathrm{Wv} / \mathrm{v}$ at pF 3.0), and small pores available water capacity - SAWC (Wv/v at pF $3.0-\mathrm{Wv} / \mathrm{v}$ at pF 4.2) were calculated (Zawadzki, 1973, Walczak et al., 2002). Redox potential (Eh) and oxygen diffusion rate (ODR) were determined with a REDOX apparatus for measuring potential and diffusion rate in soil Institute of Agrophysics, Polish Academy of Sciences in Lublin (Stępniewska 1988) and reduction rate assessment index $(\mathrm{rH})$ was calculated according to the formula: $\mathrm{rH}=\left(\mathrm{Eh} \times 29^{-1}\right)+2 \times \mathrm{pH}$

Fig. 1. Location of studied soil sites

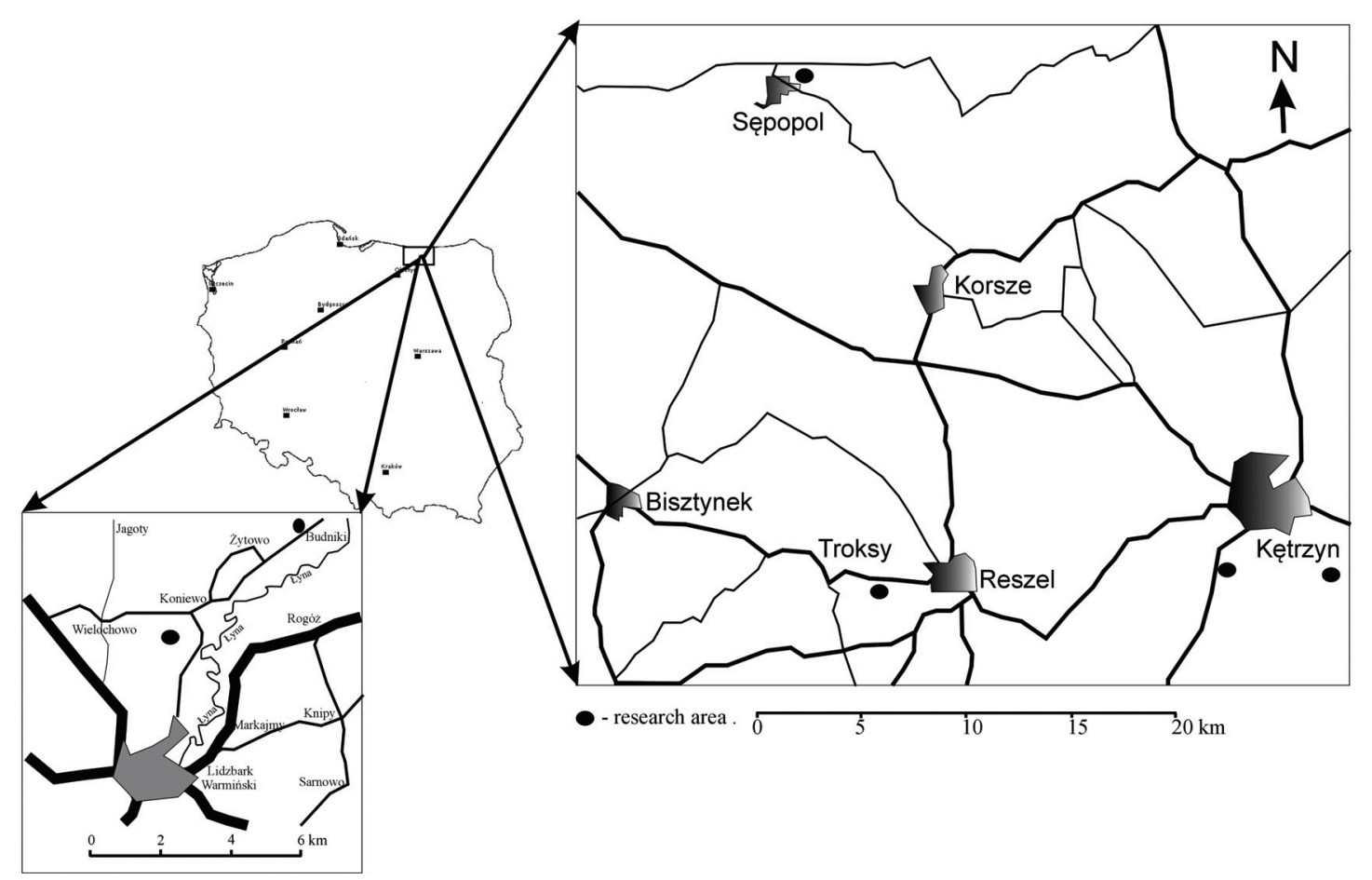


Coefficient of linear extensibility (COLE) was calculated at the soil sample moisture content corresponding to a pressure of $33 \mathrm{kPa}$.

\section{Results and discussion}

\subsection{Soil texture and some chemical properties}

The soil reaction in humic horizons (A) ranged from slightly acid $\left(\mathrm{pH}_{\mathrm{KCl}} 5.6\right)$ to neutral $\left(\mathrm{pH}_{\mathrm{KCl}}\right.$ 7.0). In the soil profiles the $\mathrm{pH}$ values were increasing with depth, and in subsurface horizons numerous carbonates precipitations occurred (Table 1). The carbonates contents in the parent material ranged from $0.6 \%$ to $16.4 \%$. The studied soils had high amounts of TOC, which in humic horizons ranged from $16.0 \mathrm{~g} \mathrm{~kg}^{-1}$ to $58.0 \mathrm{~g} \mathrm{~kg}^{-1}$. The TN content was between $1.81 \mathrm{~g} \mathrm{~kg}^{-1}$ and $3.87 \mathrm{~g} \mathrm{~kg}^{-1}$. Gleyic vertisols, which were under permanent grasslands, had the highest contents of TOC and TN. The $\mathrm{C} / \mathrm{N}$ ratio ranged from 7.3 to 15.0. Vertisols also had high CEC, above $23.81 \mathrm{cmol}(+) \mathrm{kg}^{-1}$, including the content of base cations (TEB), which was over $21.90 \mathrm{cmol}(+) \mathrm{kg}^{-1}$. A higher content of exchangeable cations in vertisols was found by Kishné et al. (2009) in the Texas Gulf Coast Prairie. The BS was very high and exceeded $89.3 \%$. It is worth emphasizing that the content of base cations and base saturation was increasing with increasing depth in the soil profiles, which indicates the leaching processes from surface horizons. A particularly high base saturation, over $97 \%$, was found in soils where precipitation of calcium carbonate occurred (Table 1).

Table 1

Chemical properties of the studied Vertisols

\begin{tabular}{|c|c|c|c|c|c|c|c|c|c|c|c|}
\hline \multirow{2}{*}{$\begin{array}{l}\text { Soil } \\
\text { horizon }\end{array}$} & \multirow{2}{*}{$\begin{array}{l}\text { Depth } \\
\mathrm{cm}\end{array}$} & \multicolumn{2}{|l|}{$\mathrm{pH}$} & \multirow{2}{*}{$\begin{array}{l}\mathrm{CaCO}_{3} \\
\%\end{array}$} & \multirow{2}{*}{$\frac{\mathrm{TOC}}{\mathrm{g} \mathrm{kg}^{-1}}$} & \multirow[t]{2}{*}{$\mathrm{TN}$} & \multirow[t]{2}{*}{$\mathrm{C} / \mathrm{N}$} & HA & TEB & CEC & \multirow{2}{*}{$\begin{array}{l}\text { BS } \\
\% \\
\end{array}$} \\
\hline & & $\mathrm{H}_{2} \mathrm{O}$ & $\mathrm{KCl}$ & & & & & \multicolumn{3}{|c|}{$\mathrm{cmol}(+) \mathrm{kg}^{-1}$} & \\
\hline \multicolumn{12}{|c|}{ R1 - Black vertisols, Pellic Vertisol (Aric, Mollic, Hypereutric, Grumic, Endostagnic) } \\
\hline Ap & $0-30$ & 7.6 & 7.0 & 1.8 & 18.7 & 1.81 & 10.3 & 0.67 & 23.65 & 24.32 & 97.2 \\
\hline A2 & $30-46$ & 7.7 & 7.0 & 1.3 & 19.5 & 1.93 & 10.1 & 0.57 & 23.97 & 24.54 & 97.7 \\
\hline Bikg & $46-100$ & 8.0 & 7.1 & 10.0 & 1.8 & 0.20 & 9.0 & 0.40 & 37.60 & 38.00 & 98.9 \\
\hline Cikg & $100-160$ & 8.1 & 7.2 & 16.4 & - & - & - & 0.84 & 47.17 & 48.01 & 98.3 \\
\hline Ckg2 & $160-180$ & 8.1 & 7.2 & 13.8 & - & - & - & 1.19 & 44.98 & 46.17 & 97.4 \\
\hline
\end{tabular}

K1 - Gleyic vertisols, Haplic Vertisol (Mollic, Hypereutric, Gleyic)

\begin{tabular}{|c|c|c|c|c|c|c|c|c|c|c|c|}
\hline A & $0-42$ & 6.8 & 6.2 & - & 58.0 & 3.87 & 15.0 & 2.32 & 25.23 & 27.55 & 91,6 \\
\hline Big & $42-85$ & 7.6 & 6.8 & - & - & - & - & 0.67 & 29.17 & 29.84 & 97.8 \\
\hline Ckgg & 85-130 & 7.8 & 6.9 & 0.6 & - & - & - & 0.48 & 41.57 & 42.05 & 98.8 \\
\hline Ckgg2 & $130-150$ & 8.1 & 7.2 & 9.7 & - & - & - & 0.52 & 47.76 & 48.28 & 98.9 \\
\hline
\end{tabular}

S1 - Typical vertisols, Haplic Vertisol (Aric, Hypereutric, Mazic)

\begin{tabular}{|c|c|c|c|c|c|c|c|c|c|c|c|}
\hline Ap & $0-32$ & 7.3 & 6.8 & - & 19.2 & 1.95 & 9.8 & 1.91 & 21.90 & 23.81 & 92.0 \\
\hline Big & $32-65$ & 7.9 & 7.0 & 1.2 & - & - & - & 1.37 & 40.01 & 41.38 & 96.7 \\
\hline Cig & 65-100 & 7.9 & 7.0 & 1.4 & - & - & - & 1.45 & 44.76 & 46.21 & 96.9 \\
\hline Ckg2 & $100-150$ & 8.1 & 7.6 & 15.2 & - & - & - & 1.02 & 49.31 & 50.35 & 97.9 \\
\hline
\end{tabular}

R2 - Typical vertisols, Haplic Verisol (Aric, Grumic, Hypereutric)

\begin{tabular}{|c|c|c|c|c|c|c|c|c|c|c|c|}
\hline Ap & $0-30$ & 7.5 & 6.9 & 4.6 & 16.4 & 1.94 & 8.4 & 0.65 & 25.57 & 26.22 & 97.5 \\
\hline Bik & $30-80$ & 8.0 & 7.1 & 5.6 & 1.1 & 0.15 & 7.3 & 0.19 & 31.10 & 31.29 & 99.4 \\
\hline Cik & 80-150 & 8.1 & 7.2 & 12.5 & - & - & - & 0.22 & 28.60 & 28.82 & 99.2 \\
\hline Ck2 & $150-180$ & 8.1 & 7.2 & 14.5 & - & - & - & 1.02 & 36.95 & 37.97 & 97.3 \\
\hline
\end{tabular}

L1 - Typical vertisols, Haplic Vertisol (Aric, Hypereutric, Grumic)

\begin{tabular}{|c|c|c|c|c|c|c|c|c|c|c|c|}
\hline A & $0-28$ & 6.3 & 5.6 & - & 16.0 & 1.85 & 8.6 & 2.71 & 22.68 & 25.39 & 89.3 \\
\hline $\mathrm{Bi}$ & $28-85$ & 6.9 & 6.0 & - & - & - & - & 1.61 & 26.83 & 28.44 & 94.3 \\
\hline Cikg & 85-150 & 7.9 & 7.1 & 14.7 & - & - & - & 1.21 & 68.92 & 70.13 & 98.3 \\
\hline Ckg2 & $<150$ & 7.9 & 7.2 & 13.1 & - & - & - & 1.18 & 69.46 & 70.64 & 98.3 \\
\hline
\end{tabular}

Explanation: HA - potential (hydrolytic) acidity; TEB - total exchangeable bases; CEC - cation exchange capacity 
The vertisols in the Sępopol Plain had the texture of clay (C), loam (L) and heavy clay (HC). In deeper horizons of the soil profiles, loam (L) and silty clay (SiC) frequently occurred. The studied soils were developed from fine-grained sediments of ice-dammed lakes origin with a high content of clay and did not contain skeletal fractions with a diameter $>2.0 \mathrm{~mm}$. The content of sand $(2.0-0.05 \mathrm{~mm}$ ) was low and ranged from $5 \%$ to $43 \%$ (Table 2). In the silt fraction $(0.05-0.002 \mathrm{~mm})$, the fine silt sub-fraction (0.02-0.002 $\mathrm{mm}$ ) prevailed, reaching 52\%. The clay fraction $(<0.002 \mathrm{~mm}$ ) amounted to up to $81 \%$ (55\% on average). Clay fraction was predominated by swelling minerals, mainly smectite and mixed-packet type of illite / smectite (I / S), with a large share of smectite packets in their structure (Długosz et al., 2009). The high content of clay fraction rich in swelling clay minerals promotes the shrinking and swelling of vertisols. The confirmation of the occurrence of the vertic horizon in the soils of the Sępopol Plain were the values of the coefficient of linear extensibility, which exceeded 0.06. In B horizons of studied vertisols, the COLE ranged from 0.116-0.205 (Table 3). The calculated correlation coefficients showed that the content of clay had a significantly positive $(r=0.651)$ and sand had a significantly negative $(r=-0.510)$ impact on the COLE values (Table 5). Kishné et al. (2009) and Reeve et al. (1980) stressed that the content of organic matter, carbonates and silica influence reduction of swelling and shrinking by increasing the cohesion forces.

Table 2

Texture of analysed Vertisols

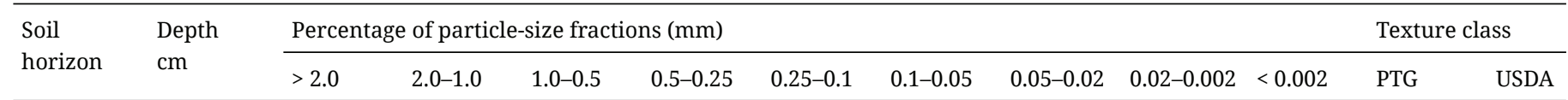

R1 - Reszel: Black vertisols - SGP6 2019, Pellic Vertisol (Aric, Mollic, Hypereutric, Grumic, Endostagnic) - WRB 2015

\begin{tabular}{|c|c|c|c|c|c|c|c|c|c|c|c|c|}
\hline Ap & $0-30$ & 0 & 1 & 2 & 5 & 7 & 10 & 11 & 21 & 43 & iz & $\mathrm{C}$ \\
\hline $\mathrm{A} 2$ & $30-46$ & 0 & 0 & 2 & 3 & 5 & 9 & 9 & 24 & 48 & iz & C \\
\hline Bikg & $46-100$ & 0 & 0 & 1 & 2 & 4 & 4 & 2 & 9 & 78 & ic & $\mathrm{HC}$ \\
\hline Cikg & $100-160$ & 0 & 0 & 1 & 2 & 4 & 3 & 2 & 19 & 69 & ic & $\mathrm{HC}$ \\
\hline Ckg2 & $160-180$ & 0 & 0 & 1 & 1 & 2 & 5 & 2 & 39 & 50 & ipy & $\mathrm{SiC}$ \\
\hline
\end{tabular}

K1 - Kętrzyn: Gleyic vertisols, Haplic Vertisol (Mollic, Hypereutric, Gleyic

\begin{tabular}{|c|c|c|c|c|c|c|c|c|c|c|c|c|}
\hline A & $0-42$ & 0 & 3 & 7 & 8 & 6 & 5 & 13 & 34 & 24 & gz & $\mathrm{L}$ \\
\hline Big & $42-85$ & 0 & 0 & 1 & 1 & 2 & 7 & 3 & 16 & 70 & ic & $\mathrm{HC}$ \\
\hline Ckgg & 85-130 & 0 & 1 & 2 & 3 & 4 & 8 & 12 & 5 & 65 & ic & $\mathrm{HC}$ \\
\hline Ckgg2 & 130-150 & 0 & 0 & 1 & 1 & 1 & 9 & 7 & 7 & 74 & ic & $\mathrm{HC}$ \\
\hline
\end{tabular}

S1 - Sępopol: Typical vertisols, Haplic Vertisol (Aric, Hypereutric, Mazic)

\begin{tabular}{|c|c|c|c|c|c|c|c|c|c|c|c|c|}
\hline Ap & $0-32$ & 0 & 3 & 5 & 6 & 10 & 13 & 16 & 24 & 23 & gz & $\mathrm{L}$ \\
\hline Big & $32-65$ & 0 & 0 & 1 & 2 & 2 & 5 & 5 & 7 & 78 & ic & $\mathrm{HC}$ \\
\hline Cig & 65-100 & 0 & 0 & 2 & 2 & 3 & 2 & 1 & 14 & 76 & ic & $\mathrm{HC}$ \\
\hline Ckg2 & $100-150$ & 0 & 4 & 6 & 10 & 12 & 11 & 7 & 33 & 17 & gz & $\mathrm{L}$ \\
\hline
\end{tabular}

R2 - Reszel: Typical vertisols, Haplic Verisol (Aric, Hypereutric, Grumic)

\begin{tabular}{|c|c|c|c|c|c|c|c|c|c|c|c|c|}
\hline Ap & $0-30$ & 0 & 2 & 2 & 5 & 7 & 5 & 6 & 21 & 52 & iz & C \\
\hline Bik & $30-80$ & 0 & 0 & 2 & 4 & 6 & 5 & 8 & 7 & 68 & ic & $\mathrm{HC}$ \\
\hline Cik & 80-150 & 0 & 0 & 1 & 2 & 3 & 4 & 2 & 20 & 68 & ic & $\mathrm{HC}$ \\
\hline $\mathrm{Ck} 2$ & $150-180$ & 0 & 0 & 0 & 1 & 1 & 3 & 2 & 52 & 41 & ipy & $\mathrm{SiC}$ \\
\hline
\end{tabular}

L1 - Lidzbark Warmiński: Typical vertisols, Haplic Vertisol (Aric, Hypereutric, Grumic)

\begin{tabular}{|c|c|c|c|c|c|c|c|c|c|c|c|c|}
\hline A & $0-28$ & 0 & 2 & 2 & 4 & 5 & 7 & 8 & 31 & 41 & $\mathrm{iz}$ & C \\
\hline $\mathrm{Bi}$ & $28-85$ & 0 & 0 & 0 & 2 & 2 & 3 & 3 & 9 & 81 & ic & $\mathrm{HC}$ \\
\hline Cikg & 85-150 & 0 & 0 & 1 & 1 & 3 & 3 & 2 & 49 & 41 & ipy & $\mathrm{SiC}$ \\
\hline Ckg2 & $<150$ & 0 & 0 & 1 & 2 & 1 & 2 & 2 & 50 & 42 & ipy & $\mathrm{SiC}$ \\
\hline
\end{tabular}

Explanation: gz - loam, ipy - silty clay, iz - clay, ic - heavy clay; L - loam, SiC - silty clay, C - clay, HC - heavy clay 


\subsection{Physical, water and retention properties}

Soil water retention and water-air relationships in mineral soils depend largely on the humus content, degree of soil compaction, soil texture including clay content and cultivation technology (Rawls et al., 1991, Tietje and Tapkenhinrichs, 1993, Castellini et al., 2019). In the studied vertisols, the bulk density, which is an indicator of soil compaction, did not exceed 1.331 $\mathrm{Mg} \mathrm{m}^{-3}$ in surface horizons (Table 3). The lowest particle density amounting to $1.150 \mathrm{Mg} \mathrm{m}^{-3}$, and the highest total porosity $51.1 \%$ $\mathrm{v} / \mathrm{v}$ was found in humic horizons of Gleyic Vertisols (Table 3). The bulk density above $1.33 \mathrm{Mg} \mathrm{m}^{-3}$ in the soils with high content of swelling clays may affect air conditions and limit oxygen mac- rodiffusion. The air pore volume in surface horizons (A) did not exceed $9.4 \% \mathrm{v} / \mathrm{v}$, and in subsurface horizons and parent material it amounted to $2.1 \% \mathrm{v} / \mathrm{v}$ (Table 4). For the proper growth and development of the root system of most cultivated crops, the volume of macropores should range from 10\% to 15\% (Jarvis and Macney, 1979). The studied vertisols had improper distribution of soil pores because the ratio of macropores to mesopores to micropores in humic horizons was 1:2.7-5.1:1.5-5.4. This ratio was particularly unfavorable in some sub-humic horizons, where the volume of micropores exceeded the volume of mesopores twice and the volume of macropores more than 10 times.

Vertisols of the Sępopol Plain had high field water capacity (pF 2.0) and high content of water unavailable to plants ( $\mathrm{pF} 4.2$ ).

Table 3

Physical and redox properties

\begin{tabular}{lllllllll}
\hline Soil horizon & Depth & $\begin{array}{l}\text { Specific } \\
\text { density }\end{array}$ & $\begin{array}{l}\text { Bulk } \\
\text { density }\end{array}$ & $\begin{array}{l}\text { Total } \\
\text { porosity } \\
\% \mathrm{v} / \mathrm{v}\end{array}$ & $\begin{array}{l}\text { Index } \\
\text { COLE }\end{array}$ & ODR & Eh & $\mathrm{rH}$ \\
& $\mathrm{cm}$ & & $\mu \mathrm{g} \mathrm{m}^{-1} \mathrm{~s}^{-1}$ & $\mathrm{mV}$ & \\
\hline
\end{tabular}

R1 - Black vertisols, Pellic Vertisol (Aric, Mollic, Hypereutric, Grumic, Endostagnic)

\begin{tabular}{llllllllll} 
Ap & & 2.377 & 1.204 & 49.3 & 0.120 & 56.1 & 310 & 24.7 \\
A2 & $30-46$ & 2.551 & 1.312 & 48.6 & 0.117 & 47.2 & 265 & 23.1 \\
Bikg & $46-100$ & 2.457 & 1.244 & 49.4 & 0.183 & 38.3 & 220 & 21.8 \\
Cikg & $100-160$ & 2.482 & 1.310 & 47.2 & 0.158 & 29.3 & 170 & 20.3 \\
Ckg2 & $160-180$ & 2.512 & 1.426 & 43.2 & 0.095 & 32.4 & 205 & 21.5 \\
\hline
\end{tabular}

K1 - Gleyic vertisols, Haplic Vertisol (Mollic, Hypereutric, Gleyic)

\begin{tabular}{llllllllll} 
A & $0-42$ & 2.351 & 1.150 & 51.1 & 0.042 & 57.4 & 305 & 22.9 \\
Big & $42-85$ & 2.558 & 1.228 & 52.0 & 0.116 & 38.4 & 265 & 22.7 \\
Ckgg & $85-130$ & 2.494 & 1.258 & 49.6 & 0.110 & 33.0 & 205 & 20.9 \\
Ckgg2 & $130-150$ & 2.457 & 1.244 & 49.4 & 0.125 & 20.5 & 155 & 19.7 \\
\hline
\end{tabular}

S1 - Typical vertisols, Haplic Vertisol (Aric, Hypereutric, Mazic)

\begin{tabular}{llllllllll} 
Ap & $0-32$ & 2.469 & 1.264 & 48.8 & 0.056 & 53.7 & 320 & 24.8 \\
Big & $32-65$ & 2.470 & 1.402 & 43.2 & 0.116 & 37.1 & 295 & 24.2 \\
Cig & $65-100$ & 2.480 & 1.383 & 44.2 & 0.104 & 29.4 & 215 & 21.4 \\
Ckg2 & $100-150$ & 2.520 & 1.460 & 42.1 & 0.032 & 19.1 & 180 & 21.4 \\
\hline
\end{tabular}

R2 - Typical vertisols, Haplic Verisol (Aric, Hypereutric, Grumic)

\begin{tabular}{llllllllll} 
Ap & $0-30$ & 2.467 & 1.312 & 46.9 & 0.107 & 58.8 & 335 & 25.4 \\
Bik & $30-80$ & 2.434 & 1.296 & 46.8 & 0.134 & 48.6 & 300 & 24.5 \\
Cik & $80-150$ & 2.438 & 1.285 & 47.3 & 0.149 & 35.7 & 255 & 23.2 \\
Ck2 & $150-180$ & 2.490 & 1.414 & 40.8 & 0.107 & 38.4 & 280 & 24.1 \\
\hline
\end{tabular}

L1 - Typical vertisols, Haplic Vertisol (Aric, Hypereutric, Grumic)

\begin{tabular}{llllllllll} 
A & $0-28$ & 2.506 & 1.331 & 46.9 & 0.198 & 53.6 & 325 & 22.0 \\
Bi & $28-85$ & 2.591 & 1.343 & 48.2 & 0.205 & 43.4 & 300 & 22.3 \\
Cikg & $85-150$ & 2.554 & 1.468 & 42.5 & 0.097 & 48.5 & 250 & 22.8 \\
Ckg2 & $<150$ & 2.548 & 1.482 & 41.8 & 0.090 & 31.9 & 210 & 21.6 \\
\hline
\end{tabular}

Explanation: ODR - oxygen diffusion rate; Eh - redox potential; $\mathrm{rH}$ - reduction rate assessment index 
Table 4

Air-water properties of studied Vertisols

\begin{tabular}{|c|c|c|c|c|c|c|c|c|c|c|c|c|c|}
\hline \multirow[t]{2}{*}{$\begin{array}{l}\text { Soil } \\
\text { horizon }\end{array}$} & \multirow[t]{2}{*}{$\begin{array}{l}\text { Depth } \\
\mathrm{cm}\end{array}$} & $\begin{array}{l}\mathrm{pF} \\
2.0 \\
\end{array}$ & 3.0 & 4.2 & $\begin{array}{l}\text { Macro- } \\
\text { pores }\end{array}$ & AWC & RAWC & SAWC & $\begin{array}{l}\text { Micro- } \\
\text { pores }\end{array}$ & $\begin{array}{l}\underline{\mathrm{Ma}} \\
\mathrm{Tp}\end{array}$ & $\begin{array}{l}\underline{\mathrm{AWC}} \\
\mathrm{Tp}\end{array}$ & $\begin{array}{l}\underline{\mathrm{Mi}} \\
\mathrm{Tp}\end{array}$ & $\begin{array}{l}\underline{\text { RAWC }} \\
\text { AWC }\end{array}$ \\
\hline & & $\% \mathrm{v}$ & & & & & & & & $\%$ & & & \\
\hline
\end{tabular}

R1 - Black vertisols, Pellic Vertisol (Aric, Mollic, Hypereutric, Grumic, Endostagnic)

\begin{tabular}{|c|c|c|c|c|c|c|c|c|c|c|c|c|c|}
\hline Ap & $0-30$ & 41.4 & 30.3 & 20.4 & 7.9 & 21.0 & 11.1 & 9.9 & 20.4 & 16.0 & 42.6 & 41.4 & 52.9 \\
\hline $\mathrm{A} 2$ & $30-46$ & 42.7 & 31.9 & 21.9 & 5.9 & 20.8 & 10.8 & 10.0 & 21.9 & 12.1 & 42.8 & 45.1 & 51.9 \\
\hline Bikg & $46-100$ & 46.2 & 38.5 & 28.4 & 3.2 & 17.8 & 7.7 & 10.1 & 28.4 & 6.5 & 36.0 & 57.5 & 43.7 \\
\hline Cikg & $100-160$ & 44.5 & 37.6 & 26.5 & 2.7 & 18.0 & 6.9 & 11.1 & 26.5 & 5.7 & 38.1 & 56.2 & 38.3 \\
\hline Ckg2 & $160-180$ & 39.4 & 28.7 & 18.5 & 3.8 & 20.9 & 10.7 & 10.2 & 18.5 & 8.8 & 48.4 & 42.8 & 51.2 \\
\hline
\end{tabular}

K1 - Gleyic vertisols, Haplic Vertisol (Mollic, Hypereutric, Gleyic)

\begin{tabular}{|c|c|c|c|c|c|c|c|c|c|c|c|c|c|}
\hline A & $0-42$ & 43.5 & 29.3 & 17.6 & 7.6 & 25.9 & 14.2 & 11.7 & 17.6 & 14.9 & 50.7 & 34.5 & 54.8 \\
\hline Big & $42-85$ & 49.1 & 41.8 & 30.0 & 2.9 & 19.1 & 7.3 & 11.8 & 30.0 & 5.6 & 36.7 & 57.7 & 38.2 \\
\hline Ckgg & 85-130 & 47.0 & 41.2 & 30.2 & 2.6 & 16.8 & 5.8 & 11.0 & 30.2 & 5.2 & 33.9 & 60.9 & 34.5 \\
\hline Ckgg2 & 130-150 & 46.9 & 40.3 & 31.1 & 2.5 & 15.8 & 6.6 & 9.2 & 31.1 & 5.1 & 32.0 & 63.0 & 41.8 \\
\hline
\end{tabular}

S1 - Typical vertisols, Haplic Vertisol (Aric, Hypereutric, Mazic)

\begin{tabular}{|c|c|c|c|c|c|c|c|c|c|c|c|c|c|}
\hline Ap & $0-32$ & 39.4 & 26.7 & 14.3 & 9.4 & 25.1 & 12.7 & 12.4 & 14.3 & 19.3 & 51.4 & 29.3 & 51.9 \\
\hline Big & $32-65$ & 41.0 & 34.9 & 27.7 & 2.2 & 13.3 & 6.1 & 7.2 & 27.7 & 5.1 & 30.8 & 64.1 & 45.9 \\
\hline Cig & 65-100 & 42.1 & 35.7 & 27.2 & 2.1 & 14.9 & 6.4 & 8.5 & 27.2 & 4.8 & 33.7 & 61.5 & 43.0 \\
\hline Ckg2 & 100-150 & 37.5 & 24.3 & 16.8 & 4.6 & 20.7 & 13.2 & 7.5 & 16.8 & 10.9 & 49.2 & 39.9 & 63.8 \\
\hline
\end{tabular}

R2 - Typical vertisols, Haplic Verisol (Aric, Hypereutric, Grumic)

\begin{tabular}{|c|c|c|c|c|c|c|c|c|c|c|c|c|c|}
\hline Ap & $0-30$ & 42.8 & 29.2 & 22.0 & 4.1 & 20.8 & 11.6 & 9.2 & 22.0 & 8.8 & 44.3 & 46.9 & 55.8 \\
\hline Bik & $30-80$ & 43.3 & 36.0 & 26.4 & 3.5 & 16.9 & 7.3 & 9.6 & 26.4 & 7.5 & 36.1 & 56.4 & 43.2 \\
\hline Cik & 80-150 & 43.9 & 36.2 & 25.5 & 3.4 & 18.4 & 7.7 & 10.7 & 25.5 & 7.2 & 38.9 & 53.9 & 41.8 \\
\hline Ck2 & 150-180 & 37.2 & 29.8 & 19.2 & 3.6 & 18.0 & 7.4 & 10.6 & 19.2 & 8.8 & 44.1 & 47.1 & 41.1 \\
\hline
\end{tabular}

L1 - Typical vertisols, Haplic Vertisol (Aric, Hypereutric, Grumic)

\begin{tabular}{|c|c|c|c|c|c|c|c|c|c|c|c|c|c|}
\hline A & $0-28$ & 40.1 & 27.5 & 17.8 & 6.8 & 22.3 & 12.6 & 9.7 & 17.8 & 15.0 & 47.5 & 38.0 & 56.5 \\
\hline $\mathrm{Bi}$ & $28-85$ & 46.0 & 37.0 & 23.4 & 2.2 & 22.6 & 9.0 & 13.6 & 23.4 & 4.6 & 46.9 & 48.6 & 39.8 \\
\hline Cikg & $85-150$ & 38.2 & 25.4 & 17.1 & 4.3 & 21.1 & 12.8 & 8.3 & 17.1 & 10.1 & 49.6 & 40.2 & 60.7 \\
\hline Ckg2 & $<150$ & 38.2 & 26.4 & 17.6 & 3.6 & 20.6 & 11.8 & 8.8 & 17.6 & 8.6 & 49.3 & 42.1 & 57.3 \\
\hline
\end{tabular}

Explanation: AWC - available water capacity; RAWC - readily available water capacity; SAWC - small pores available water capacity; Ma - macropores; $\mathrm{Mi}$ - micropores; Tp - total porosity

The volume of field water capacity (pF 2.0) in humic horizons was from $39.4 \% \mathrm{v} / \mathrm{v}$ to $43.5 \% \mathrm{v} / \mathrm{v}$, including the volume of water available to plants (AWC), which ranged from 20.8 to $25.9 \% \mathrm{v} / \mathrm{v}$ (Table 4). Walczak et al. (2002) as well as Orzechowski and Smólczyński (2010) found similar values of water retention properties in alluvial soils developed from clay deposits. Water resources corresponding to the field water capacity (pF 2.0) in the studied soils were high and in the $0-0.3 \mathrm{~m}$ soil layer they ranged from $118.2 \mathrm{~mm}$ to $130.5 \mathrm{~mm}$, while in the 0-0.5 m layer they were between 199.9 and $228.7 \mathrm{~mm}$ (Fig. 2, 3). In the studied vertisols, approximately $50 \%$ of water resources of field water retention were available to plants (AWC), and in the $0-0.3 \mathrm{~m}$ layer these resources oscillated between $62.4 \mathrm{~mm}$ and $77.7 \mathrm{~mm}$, and in the $0-0.5 \mathrm{~m}$ layer between $96.2 \mathrm{~mm}$ and $115.9 \mathrm{~mm}$. The highest water retention and water resources available to plants were found in gleyic vertisols (K1) (Fig. 2, 3). The share of water unavailable to plants (pF 4.2) in field water capacity was substantial, and ranged from 14.3\%-22.0\% $\mathrm{v} / \mathrm{v}$ in humic horizons (Table 4). However, in B horizons and some parent materials (C), due to the high content of clay and high soil compaction, the water in micropores, which is unavailable to plants, prevailed. The share of water available to plants in total porosity (AWC/Tp) rarely exceeded $50 \%$, and the share of water unavailable to plants in total porosity (Micropores/Tp) ranged from $29.3 \%$ to $64.1 \%$. In the volume of water available to plants 
(AWC), the share of water readily available to plants (RAWC) in humic horizons was higher than the content of water hardly available to plants, i.e. water in small pores (SAWC). On the other hand, in B horizons developed from heavy loam, the share of water readily available to plants was lower than water hardly available to plants and ranged from $38.2 \%$ to $45.9 \%$. A similar RAWC/ AWC ratio was found by Orzechowski and Smólczyński (2010) in black earths developed from clay and in heavy alluvial soils.
The calculated correlation coefficients showed a significantly positive relationship between the amount of clay and the volume of water unavailable to plants ( $\mathrm{r}=0.880)$, and negative for water available to plants (AWC, $r=-0.711$ ), including water readily available for plants (RAWC, $r=-0.852$ ). The fine silt fraction $(0.02-0.002 \mathrm{~mm})$ had a significant positive impact on the volume of water available to plants $(r=0.467)$, including water readily available to plants $(r=0.621)$, (Table 5$)$.

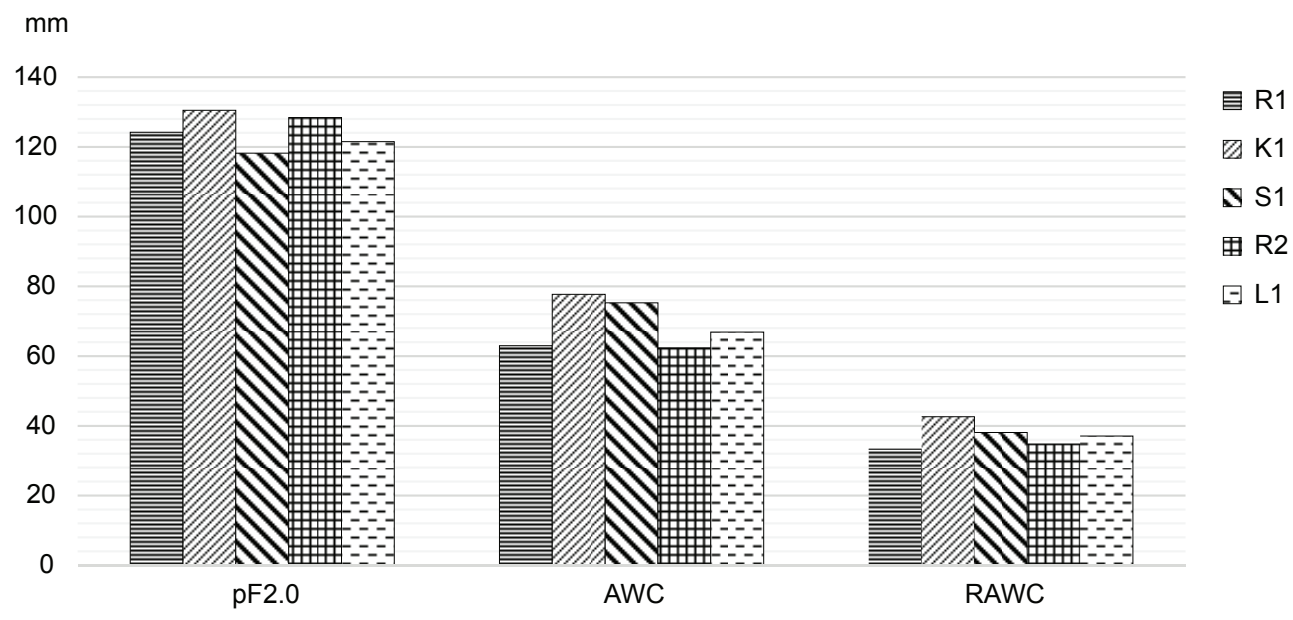

R1, R2 - Reszel, K1 - Kętrzyn, S1 - Sępopol, L1 - Lidzbark Warmiński

Fig. 2. Water resources in $0.3 \mathrm{~m}$ soil layer

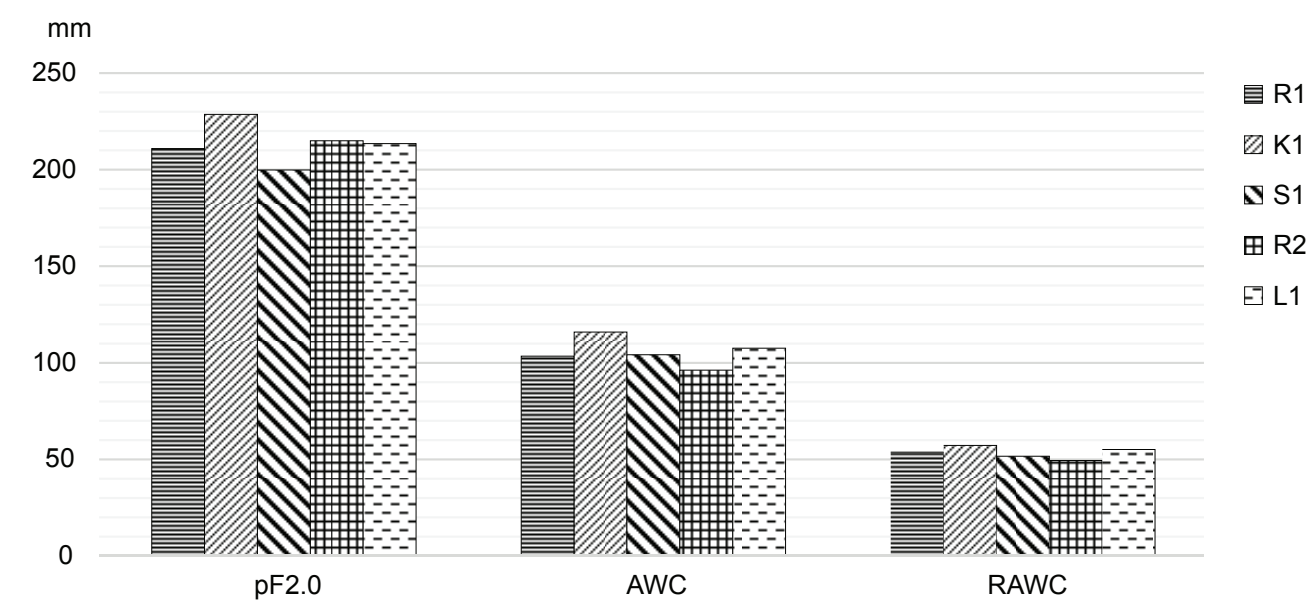

Fig. 3. Water resources in $0.5 \mathrm{~m}$ soil layer

Table 5

Coefficients of correlation between granulometric fractions and soil retention properties

\begin{tabular}{|c|c|c|c|c|c|c|c|c|c|c|}
\hline \multirow{2}{*}{$\begin{array}{l}\text { Content of fraction } \\
\text { with a diameter of } \\
\text { [mm] }\end{array}$} & $\begin{array}{l}\text { Total } \\
\text { porosity }\end{array}$ & pF 2.0 & $\begin{array}{l}\text { Macro- } \\
\text { pores }\end{array}$ & AWC & RAWC & $\begin{array}{l}\text { Micro- } \\
\text { pores }\end{array}$ & \multirow{2}{*}{$\begin{array}{l}\mathrm{Eh} \\
\mathrm{mV}\end{array}$} & ODR & COLE & \multirow[t]{2}{*}{$\mathrm{rH}$} \\
\hline & & & $\% \mathrm{v} / \mathrm{v}$ & & & & & $\mu \mathrm{g} \mathrm{m}^{-1} \mathrm{~s}^{-1}$ & & \\
\hline $2.0-0.05$ & 0.227 & -0.207 & 0,282 & $0.503^{*}$ & $0.580^{*}$ & $-0.441^{*}$ & 0.210 & 0.244 & $-0.510^{*}$ & 0.232 \\
\hline $0.05-0.02$ & $0.488^{*}$ & 0.023 & 0,191 & $0.441^{*}$ & 0.372 & -0.252 & 0.382 & $0.464^{*}$ & -0.353 & 0.299 \\
\hline $0.02-0.002$ & $-0.596^{*}$ & $-0.769 *$ & 0.060 & $0.467^{*}$ & $0.621^{*}$ & $-0.789^{*}$ & 0.023 & 0.103 & -0.407 & 0.080 \\
\hline$<0.002$ & 0,223 & $0.683^{*}$ & -0.224 & $-0.711^{*}$ & $-0.852^{*}$ & $0.880^{*}$ & -0.211 & -0.307 & $0.651^{*}$ & -0.247 \\
\hline
\end{tabular}

* - significance level at $\mathrm{a}=0.05$ 


\subsection{Redox properties}

In the studied soils, the values of redox potential (Eh), oxygen diffusion rate (ODR) and reduction rate assessment index $(\mathrm{rH})$ were low, which proves unfavorable aerobic conditions (Table 3). The values of Eh exceeded $300 \mathrm{mV}$, the threshold value for oxygenated/reduced soils, only in surface horizons of the studied vertisols. At subsurface horizons, the Eh was below $300 \mathrm{mV}$, which is associated with the reduction of manganese and iron compounds (Gliński and Stępniewska, 1986: Stępniewska, 1988). The values of ODR ranged from 53.6 to $58.8 \mu \mathrm{g} \mathrm{m}^{-2} \mathrm{~s}^{-1}$ in surface horizons. In deeper horizons the ODR values did not exceed $50.0 \mu \mathrm{g} \mathrm{m}^{-2} \mathrm{~s}^{-1}$, which indicates the possibility of hypoxia of the root system of most cultivated crops. In parent materials of black vertisols and gleyic vertisols and some typical vertisols, the ODR values did not exceed $35.0 \mu \mathrm{g} \mathrm{m}^{-2} \mathrm{~s}^{-1}$, which is the value of lower critical oxygenation limit for plants (Gliński and Stępniewska, 1986). High water content in soil and simultaneous high content of swelling clay minerals and low volume of air pores promotes gleyic processes, as indicated by redoximorphic parameters. Limited macrodiffusion in the studied vertisols may limit the oxygen supply to the plant root system, hamper its development and even cause plant dying. It is particularly important in clay soils, which have high potential fertility but unfavorable air-water relations resulting from the small volume of air popres (Stępniewski 1980). Unfavorable aerobic conditions in soils developed from glaciolimnic sediments in the Sępopol Plain were also confirmed by the studies of Orzechowski et al. (2018). The values of $\mathrm{rH}$ exceeded 20.0 in the studied soils, but this was mainly due to the neutral reaction of soils, which has a key impact on its value.

The values of the redox potential, oxygen diffusion rate and rH index were negatively correlated with clay content, but these relationships were not statistically significant (Table 5).

\section{Conclusions}

1. Vertisols in the Sępopol Plain were developed from glaciolimnic sediments and had textures of clay (C), loam (L) and heavy clay (HC).

2. The studied vertisols had high field water capacity (pF 2.0) and the content of water unavailable to plants (pF 4.2). Only in humic horizons the volume of water available to plants (AWC) was higher than the volume of water unavailable to plants.

3. Studied vertisols had low volume of air pores. The distribution of soil pores was unfavorable, and the ratio of macropores to mesopores to micropores in humic horizons was as 1:2.7-5.1:1.5-5.4.

4. The studied vertisols had unfavorable aerobic conditions, which was proved by low values of redox potential (Eh) and oxygen diffusion rate (ODR). The values of Eh exceeded $300 \mathrm{mV}$, which is a threshold value for oxygenated / reduced soil.

\section{Acknowledgments}

The research was financed by University of Warmia and Mazury in Olsztyn, Department of Soil Science and Reclamation

\section{References}

Ahmad, N., 1996. Occurrence and distribution of Vertisols. Developments in soil science $24,1-41$.

Castellini, M., Fornaro, F., Garofalo, P., Giglio, L., Rinaldi, M., Ventrella, D., Vitti, C., Vonella, A.V., 2019. Effectsof no-tillage and conventional tillage on physical and hydraulic properties of fine textured soils under winter wheat. Water 11, 484. https://doi.org/10.3390/w11030484

DeCarlo, K.F., Caylor, K.K., 2019. Biophysical effects on soil crack morphology in faunally active dryland vertisol. Geoderma 334, 134-145. https://doi.org/10.1016/j.geoderma.2018.07.042

Długosz, J., Orzechowski, M., Kobierski, M., Smólczyński, S., Zamorski, R., 2009. Clay minerals from Weichselian glaciolimnic sediments of the Sępopolska Plain (NE Poland). Geologica Carpathica 60(3), 263-267. https://doi.org/10.2478/v10096-009-0018-z

Dudek, M., Waroszewski, J., Kabała, C., Łabaz, B., 2019. Vertisols properties and classification in relation to parent material differentiation near Strzelin (SW Poland). Soil Science Annual 70(2), 158-169. https://doi.org/10.2478/ssa-2019-0014

Favre, F., Boivin, P., Wopereis, M.C.S., 1997. Water movement and soil swelling in a dry, cracked Vertisol. Geoderma 78(1), 113-123. https://doi.org/1016/S0016-7061(97)00030-X

Gliński, J., Stępniewska, Z., 1986. An evaluation of soil redox resistance to reduction processes. Polish Journal of Soil Science 19, 15-19.

IUSS Working Group WRB, 2015. World reference base for soil resources 2014, update 2015. International Soil Classification System for Naming Soil and Creating Legends for Soil Maps. Food and Agriculture Organization of the Unit Nations, Rome, $190 \mathrm{pp}$.

Jarvis, M.G., Macney, D., 1979. Soil survey applications. Technical Monograph., Haperden 13, 24-34.

Kabala, C., Plonka, T., Przekora, A., 2015. Vertic properties and gilgai-related subsurface features in soils of south-western Poland. Catena 128, 95-107. https://doi.org/10.1016/j.catena.2015.01.025

Kabała, C. et al., 2019. Polish Soil Classification, $6^{\text {th }}$ edition - principles, classification scheme and correlations. Soil Science Annual 70(2), 71-97.

Kishné, A.S., Morgan, C.L.S., Miller, W.L., 2009. Vertisol crack extent associated with gigai and soil moisture in the Texas Gulf Coast Prairie. Soil Science Society of American Journal 73, 1221-1230. https://doi. org/10.2136/sssaj2008.0081

Kovda, I.V., Wilding, L.P., 2004. Vertisols: problems of classification, evolution and spatial self-organization. Eurasian Soil Science 37(12), 1341-1351.

Körnke, B., 1930. Letztglazialer Eisabbau und Flussgeschichte im nördlichen Ostpreeussen und seiner Nachbargebiten. Zeitschrift der Deutschen Geologischen Gesellschaft 82, 14-33.

Łabaz, B., Kabała, C., 2014. Origin, properties and classification of black earths in Poland. Roczniki Gleboznawcze - Soil Science Annual 65(2), 80-90. https://doi.org/10.2478/ssa-2014-0012

Miller, W.L., Kishne, A.S., Morgan, C.L., 2010. Vertisol morphology, classification, and seasonal cracking patterns in the Texas Gulf coast prairie. Soil Horizons 51(1), 10-16. http://doi.org/10.2136/sh2010.1.0010

Mocek, A., Owczarzak, W., Tabaczynski, R., 2009. Particle-size distribution of soils and mineralogical composition of clay fraction in Gniew Phaeozems. Roczniki Gleboznawcze - Soil Science Annual 60(3), 123-132. 
Olszewski, Z., 1956. Heavy Ciechanów soils. Roczniki Nauk Rolniczych 75-D, 269-316.

Orzechowski, M., Smólczyński, S., 2010. Air-water properties of alluvial and deluvial soils in various landscapes of north-eastern Poland. Polish Journal of Soil Science 43(2), 103-113.

Orzechowski, M., Smólczyński, S., Długosz, J., Kalisz, B., Kobierski, M., 2018. Content and distribution of iron forms in soils formed from glaciolimnic sediments, in NE Poland. Journal of Elementology 23(2), 729-744. DOI: 10.5601/jelem.2017.22.4.1413 http://doi.org/10.5601/ jelem.2017.22.4.1413

Polish Soil Classification, 2011. Roczniki Gleboznawcze - Soil Science Annual 62(3), 1-193. (in Polish with English summary)

Prusinkiewicz, Z., 2001. Gniew smolnice (vertisols) - properties, origin, systematics. Roczniki Gleboznawcze - Soil Science Annual 52(1/2), $5-21$.

Reeve, M.J., Hall, D.G.M., Bullock, P., 1980. The effect of soil composition and environmental factors on the shrinkage of some clayey British soils. Journal of Soil Science 31, 429-442. https://doi.org/10.1111/ j.1365-2389.1980.tb02092.x

Rawls, W.J., Gish, T.J, Brakensiek, D.L., 1991. Estimating soil water retention from soil physical properties and characteristics. Advances in Soil Science 16, 213-234.

Roszko, L., 1968. Recession of the last ice sheet from Poland. Prace Geograficzne 74. PWN Warszawa, 65-110.
Stępniewska, Z., 1988. Redox properties of mineral soils of Poland. Problemy Agrofizyki 56, 108 pp.

Stępniewski, W., 1980. Dependence of oxygen diffusion and compactness on soil compaction. Rozprawa habilitacyjna. Zakład Agrofizyki PAN Lublin, $54 \mathrm{pp}$.

Suchecki, S., 2010. Ecoclimate of north-eastern Poland. ALGRAF s.c., 148 pp.

Tietje, O., Tapkenhinrichs, M., 1993. Evaluation of pedo-transfer functions. Soil Science Society of America Journal 57, 1088-1095. https://doi.org/10.2136/sssaj1993.03615995005700040035x

Uggla, H., Witek, T., 1956. Black earths of Kętrzyn. Zeszyty Naukowe WSR w Olsztynie 3, 69-108.

Van Reeuwijk, LP. (Ed.). 2002. Procedures for soil analysis. Technical Paper 9. ISRIC, FAO, Wageningen.

Walczak, R., Ostrowski, J., Witkowska-Walczak, B., Sławiński, C., 2002. Hydrophysical characteristics of mineral Polish soils. Acta Agrophysica 79(5), $64 \mathrm{pp}$.

Wilding, L.P., 2004. Advancement in the knowledge base of Vertisols genesis, classification, distribution and management. Revista Cientifica Agropecuaria 8, 45-54.

Zawadzki, 1973. Laboratory analyses of soil water retention. Wiadomości IMUZ 11(2), 11-31.

\section{Słowa kluczowe}

Wertisole

Osady glacjolimniczne

Właściwości fizyczne

Retencja wody

Potencjał oksydoredukcyjny
Fizyczne, wodne i oksydoredukcyjne właściwości wertisoli na Nizinie Sępopolskiej w Polsce północno-wschodniej

\section{Streszczenie}

Wertisole występujące na terenie Niziny Sępopolskiej w Polsce północno-wschodniej charakteryzują się naturalną wysoką żyznością. Należą one do grupy gleb o dużej zawartości frakcji iłowej, które wykazują zdolności do cyklicznego kurczenia się i pęcznienia minerałów ilastych. W wyniku zmiennego uwilgotnienia w glebach tych tworzą się głębokie szczeliny i gładkie powierzchnie ślizgu na powierzchni agregatów. Celem niniejszej pracy było zbadanie właściwości chemicznych, fizycznych, powietrzno-wodnych i oksydoredukcyjnych wertisoli wytworzonych z zastoiskowych osadów glacjolimnicznych zlodowacenia bałtyckiego. Badane wertisole wytworzyły się z drobnoziarnistych osadów glacjolimnicznych o uziarnieniu iłu zwykłego (C), gliny zwykłej (L) i iłu ciężkiego (HC). Gleby te charakteryzowały się dużą polową pojemnością wodną (pF 2,0) i zawartością wody niedostępnej dla roślin (pF 4,2), a małą objętość porów powietrznych. Stwierdzono istotną dodatnią korelację pomiędzy ilością frakcji iłowych, a objętością wody niedostępnej dla roślin (pF 4.2), natomiast ujemną zależność w odniesieniu do wody ogólnie dostępnej (AWC), w tym wody łatwo dostępnej dla roślin (RAWC). Rozkład porów glebowych był niekorzystny, a stosunek makroporów do mezoporów i mikroporów w poziomach próchnicznych kształtował się jak $1: 2.7-$ $5.1: 1.5-5.4$. Wertisole te charakteryzowały się niekorzystnymi warunkami oksydoredukcyjnymi o czym świadczą niskie wartości potencjału redox (Eh) i natężenia dyfuzji tlenu (ODR). Wartości potencjału Eh jedynie w poziomach powierzchniowych przekraczały wielkość $300 \mathrm{mV}$, przyjętą jako granica pomiędzy glebą natlenioną, a zredukowaną. 